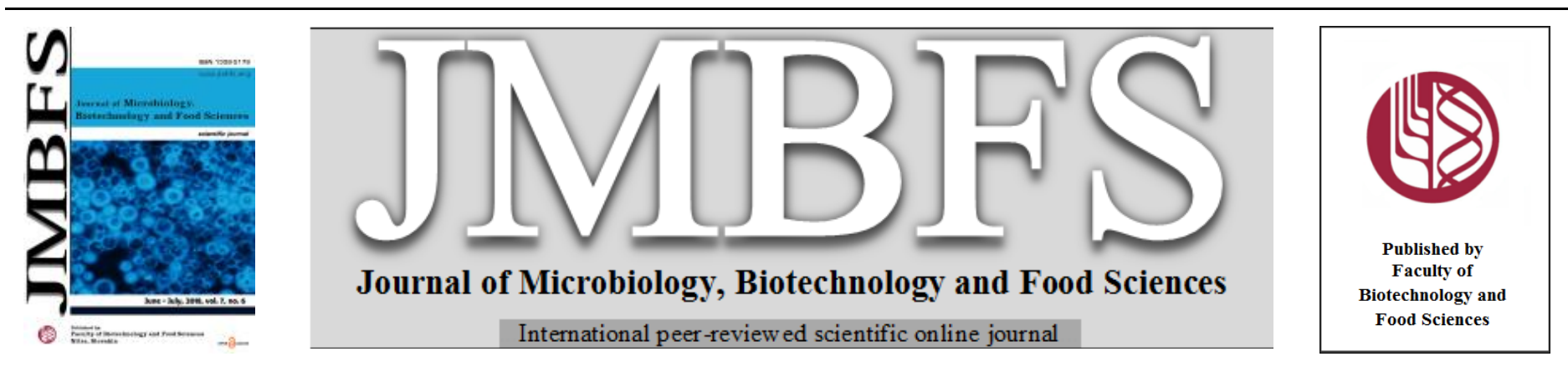

\title{
THE EFFECTS OF DRIED FAECAL SLUDGE AND MUNICIPAL WASTE CO-COMPOST ON MICROBIAL LOAD AND YIELD OF CABBAGE (Brassica oleracea L. var. capitata) AND LETTUCE (Lactuca sativa)
}

\section{Selorm Torgbo *1,2, Emmanuel Annang Quaye ${ }^{2}$, Thomas Apusiga Adongo ${ }^{3}$ and Nelson Opoku ${ }^{2}$}

\section{Address(es):}

${ }^{1}$ Biotechnology of Biopolymers and Bioactive Compounds Special Research Unit, Department of Biotechnology, Faculty of Agro-Industry, Kasetsart University, Chatuchak, Bangkok 10900, Thailand.

${ }^{2}$ Department of Biotechnology, Faculty of Agriculture, University for Development Studies Tamale, Ghana.

${ }^{3}$ Department of Agricultural Mechanization and Irrigation Technology, Faculty of Agriculture, University for Development Studies Tamale, Ghana.

*Corresponding author: selorm.t@ku.th

doi: 10.15414/jmbfs.2018.7.6.555-561

\section{ARTICLE INFO}

Received 8. 3. 2018

Revised 13. 3. 2018

Accepted 9. 4. 2018

Published 1. 6. 2018

Regular article

OPEN $\partial_{\text {ACCESS }}$

\begin{abstract}
Municipal waste management has been of major concern to many developing countries and is presently one of the subjects under discussion due to rapid industrialization and population growth. Most of these municipal wastes have the potential of being recycled and use in crop production. They are gradually becoming a problem in Ghana instead of being used for purposes to benefit human kind. In this study, dried faecal sludge and municipal waste co-compost was used as an organic fertilizer to cultivate cabbage and lettuce to assess its effects on their microbial load and yield. The yields of vegetables increased significantly with the application of recommended doses of the co-compost. The analysis of microbial load on the vegetables also showed significantly low microbial load on vegetables cultivated on co-compost plots followed by the chemical fertilizer and control. The presences of faecal coliforms such as Salmonella spp., Shigella spp., Escherichia coli, and Klebsiella spp. were confirmed in all. The performance of vegetable cultivated on plots treated with the co-compost makes it a good source of plant nutrients to be recommended to farmers. This could also serve as prudent strategy for managing municipal waste and faecal sludge to avoid impact of unscientific disposal on public health and quality of life.
\end{abstract}

Keywords: cabbage, co-compost, lettuce, microbial load, municipal waste management

\section{INTRODUCTION}

Municipal waste are heterogeneous in nature and are generated from several sources with varying human activities on daily basis (Valkenburg et al., 2008; Hering, 2012; Miezah et al., 2015; Gu et al., 2016). A number of studies revealed about $55-80 \%$ of the municipal waste are generated by households in developing countries, and the key component of this waste includes; yard waste, food waste, wood, plastics, papers, rubbers, inert materials and sundry (Nabegu, 2010; Nagabooshnam, 2011; Okot-Okumu, 2012; Miezah et al., 2015). Whereas in developing countries, the average daily faecal excretion per person range between $0.35 \mathrm{~kg}$ to $0.25 \mathrm{~kg}$ in rural and urban areas respectively (Feachem et al., 1983; Nartey, 2013).

In Ghana, average waste generated per person in the municipalities on daily basis is about $0.47 \mathrm{~kg}$, which includes those mentioned earlier (Miezah et al., 2015). The way in which these waste are managed could have a profound impact on public health and quality of life in municipalities (Agbede and Ajagbe, 2004; Wilson et al., 2015). Most of these wastes usually find their way into landfill sites creating environmental problems such as a route of transmission for disease and deprives humanity of valuable soil fertility, especially in urban centers. It is also one of the primary ingredients in sewage, and is largely responsible for much of the world's water pollution (UNEP-IETC, 1996; Wilson et al., 2013; Wilson et al., 2015).

There are many different waste management strategies that could be employed. In recent times, there has been a change towards a new management sequence of command that promotes the reduction, reuse and recycling of waste products (Magrinho et al., 2006; Banar et al., 2009; Hotta, 2014; Yano and Sakai, 2016). The simplest way to tackle the waste management problem is to reduce waste at source (Fullen et al., 2013; Hotta, 2014), but it is preferable to reuse and recycle the waste where waste reduction is not achievable (Yano and Sakai, 2016; Matsuda et al., 2017). Nonetheless, most of these organic wastes have the potential of being recycled and use in agriculture systems (Soliva Torrentó and Felipó, 2002). Human excreta for that matter have traditionally been used for crop fertilization in many countries. In some Asia countries, faecal matter has been recycled and used effectively in cultivation of crops whiles its use in Africa has not received much attention (Nartey, 2013).
According to (Rekhi et al., 2000), the continues application of higher amount of only inorganic fertilizer had deleterious effect leading to decline in productivity due to limitations of one or more micronutrients. Although the use of organic fertilizer is one of the oldest practices in crop production especially where these organic sources are in abundance, it should be noted that the use of fresh manure is not recommended due to its burning effects on plants, especially young seedlings (Oelhaf, 1978; Escobar et al., 2007; KUMAR, 2013). Among the essential elements needed by crops, nitrogen is the element that limits growth the most. Nitrogen deficiency is also more likely to occur where immature cocompost is used because the microbes compete with the crops for nitrogen during the decomposition process (Oelhaf, 1978; Escobar et al., 2007; KUMAR, 2013). Humans excrete roughly $1.6 \mathrm{~kg}$ to $7.5 \mathrm{~kg}$ of fertilizer each year, primarily nitrogen, phosphorus and potassium (Wolgast, 1993; Richert et al., 2010; Schuster-Wallace et al., 2015). The treatment of human excreta as a resource rather than waste, recovery and recycling of the nutrients is essential for prevention of pollution and diseases (Shiralipour et al., 1992; Esrey et al., 1998; Magrinho et al., 2006; Cordell et al., 2009; Cordell et al., 2011). The inoffensive material obtained from recycling could be applied to the soil to increase the organic matter content, improve water holding capacity and increase the availability of nutrients for plants. In addition, it has lower concentration of heavy metals than artificial phosphorus fertilizers and farmyard manure which is added advantage (Shiralipour et al., 1992; Esrey et al., 1998; Schönning et al., 2002; Guzha et al., 2005; Niwagaba et al., 2009; Yadav et al., 2010). The objective of our study was to investigate the effect of dried faecal sludge and municipal waste co-compost, on the yield and microbial load on lettuce and cabbage. The presence of possible pathogenic microbes were also considered in the study as well, to assess the efficiency of the technique for managing municipal waste in developing countries. To prevent the hazardous impact on all components of the environment and human health, and the suitability of the cocompost in meeting agricultural needs. 


\section{EXPERIMENTAL}

\section{Study Location}

The experiment was carried out at the Farm for the Future, and the Spanish Laboratory of the University for Development Studies (UDS) Nyankpala Campus, in the Tolon District of Northern Region, Ghana. The experiment took place within a period of seven months (November 2013 to May 2014). The study area lies in the Guinea Savanna Zone, which is characterized by large areas of low grassland interspersed with trees.

\section{Experimental Design}

The experiment was laid in a randomized complete block design (RCBD) with three blocks (Table 1). Each treatment (T) was replicated four times. Table 1 Experiment layout in randomized complete block design (RCBD)

T2

T3

T1

$\mathrm{T} 2$

T2

$\mathrm{T} 1$

Legend: T1- control, T2- chemical fertilizer and T3- co-compost

\section{Preparation of Co-compost}

The co-compost used for the experiment was prepared at the Farm for the Future University for Development Studies by Agricultural Mechanization and Irrigation Technology department. The materials used for the co-compost preparation were organic municipal waste and dried faecal sludge as main co-composting materials, neem leaves and water.

Windrow method of co-composting was used in the co-compost preparation in piles consisting of two materials in a proportion of 1:2 in which the base material (human faecal waste) is the 2 units. The co-composting period lasted for eight weeks. In brief, dried neem leaves were added to each pile followed by thorough mixing of the pile and water was added intermittently. 'Zana' mats were used to cover the pile after finishing to prevent excessive water loss. Daily watering of the piles was carried out, and after every fortnight the temperature of the pile was taken and the pile turned. Samples were taken after each turning for laboratory analysis. All stages of the decomposing analysis were carried out at Savannah Agricultural Research Institute (SARI) Laboratory.

\section{Agronomic Practice}

A raised nursery bed of $2 \mathrm{~m} \times 1 \mathrm{~m}$ was laid and sterilized using rice husk. The bed was tapped at one side to avoid water logging on the bed in case of excessive watering. Cabbage seeds (Oxylus) and lettuce seeds were nursed on nursery beds and transplanted 2-3 weeks after germination. Planting was done at a spacing of $60 \mathrm{~cm} \times 60 \mathrm{~cm}$ and $30 \times 30$ for the cabbage and the lettuce respectively.

The experimental field was ploughed and harrowed with a total of $12(2.5 \mathrm{~m} \mathrm{x}$ $1.5 \mathrm{~m})$ experimental units laid. Thirty kilogram $(30 \mathrm{~kg})$ of the co-compost was incorporated into the soil of each plot, watered for one week before transplanting. Fifteen grams (15g per plant) of NPK 15:15:15 fertilizer was applied two weeks after transplanting, using ring placement method about $5 \mathrm{~cm}$ from the base as a treatment. Plots without application of any treatment were used as a control. Weeding was done twice in a month throughout the production season with a hoe and cutlass coupled with two spraying regimes at vegetative growth and head formation stages for controlling insect pests such as caterpillars, beetles, thrips, leaf worm and aphids.

\section{Data Collection}

The parameters measured in this experiment on per plot basis were head weight and head diameter for cabbage and height, number of leaves, weight after harvesting and root weight after harvesting for lettuce randomly on selected plants from each plot at three (3) weeks after transplanting.

Five tagged plants were randomly sampled from each plot. The weights of these heads were taken using an electronic weighing scale (Jadever, JPS-1050). The diameters of these heads were taken using measuring rule in centimeters $(\mathrm{cm})$ The heights of the selected plants were measured and the leaves also counted at one (1) week interval. The roots of each selected plant were cut and the plant weighed without the roots and root separately recorded at harvesting.

\section{Microbial Analysis}

A sample of the faecal sludge and municipal waste co-compost were taken to the laboratory for analysis before its application on the field. The harvested samples of cabbage and lettuce heads were also taken to the laboratory in ice-chest for microbial analysis. All samples were collected in sterilized plastic bag before taken to the laboratory.

For microbial count, $10 \mathrm{~g}$ of the co-compost was weighed and transferred into $250 \mathrm{ml}$ beaker containing $90 \mathrm{ml}$ of sterile distilled water and shake vigorously to obtain a homogenous mixture. One milliliter of the suspension from the beaker was serially diluted in test tube labeled $10^{-2}$ to $10^{-7}$ each containing $9 \mathrm{mls}$ sterilized distilled water. One milliliter aliquot of each dilution was then plated on each replicate plate and incubated for $24 \mathrm{hrs}$ at $30^{\circ} \mathrm{C}$. After incubation for $24 \mathrm{hrs}$, viable colonies on each plate was counted under magnified colony counter and data recorded as colony forming units $(\mathrm{cfu} / \mathrm{ml})$. The number of colony forming units per $\mathrm{ml}$ of the sample was calculated as follows; $\mathrm{CFU} / \mathrm{ml}=\mathrm{CFU} \mathrm{x}$ dilution factor $\mathrm{x} 1 /$ aliquot.

One gram of randomly selected samples from each plot were weighed into a beaker with $9 \mathrm{ml}$ of sterilized distilled water and macerated. Each macerated sample was then serially diluted up to the dilution factor of $10^{-2}$ to $10^{-7}$ and $10^{-2}$ up to $10^{-5}$ was used for the cabbage and lettuce respectively After incubation for $24 \mathrm{hrs}$, viable colonies on each plate was counted as above.

\section{Identification of Microbial Isolate}

Biochemical characterization was carried out and the isolates identified with the aid of Bergey's manual of determinative bacteriology (Garrity, 2006). In order to confirm whether the bacteria load on the samples were harmful (gram negative) non-harmful (gram positive). Further pure culturing by streaking method was carried out using MacConkey media. The culture was streaked on the solidified media using inoculation loop and incubated for 24 hours at $37^{\circ} \mathrm{C}$ to determine lactose fermenting (lactose positive and lactose negative) bacteria. Subsequently, citrate test as described by (Simmons, 1926) was used to differentiate gram negative bacteria that use sodium citrate as a source of carbon. The isolates were identified based on colour change. This was followed by carbohydrate fermentation test as described by (Reiner, 2012) to detect the ability of microorganisms to ferment a specific carbohydrate. The carbohydrates used for the tested were glucose, manitol, sucrose and lactose. $5 \mathrm{ml}$ of broth was dispensed into test tubes containing inverted Durham tubes which were then sterilized and inoculated under a laminar flow hood. The isolates were identified based on a change in colour of the medium and gas collected in the inverted Durham tube. Fermentation patterns were used to differentiate among bacterial groups or species. Successively, catalase test was also carried out using the drop method (Reiner, 2010). A drop of hydrogen peroxide $\left(\mathrm{H}_{2} \mathrm{O}_{2}\right)$ was added onto sterilized microscope slide and small amount of colony from the pure culture was added, and mix with sterilized toothpick. The formation of bubble was used to differentiate catalase positive bacteria from catalase negative ones. The rapid evolution of $\mathrm{O}_{2}$ as evidenced by bubbling indicates positive result. The pure culture isolates were finally cultured on selective and differential medium (salmonella and shigella-SS) agar for the identification of gram negative microorganisms (salmonella and shigella). The solidified medium was streak with the inoculum using a sterile loop and the plates incubated aerobically at $37^{\circ} \mathrm{C}$ for 24 hours. The morphology of colonies were examined and compared with references for confirmation.

\section{Statistical analysis}

Data collected during the study were entered into EXCEL spreadsheet and analyzed by analysis of variance (ANOVA) at 5\% level of significance using statistical software GenStat ( $12^{\text {th }}$ edition).

\section{RESULTS}

\section{Head Diameter of Cabbage}

There was significant difference $(\mathrm{p}<0.05)$ observed in the head diameter of cocompost treated plants compared to the control treatment plants (Figure 1). There was no significant difference between the chemical fertilizer and control. Cocompost treated plants recorded the highest diameter of $7.89 \mathrm{~cm}$ followed by chemical fertilizer which had a diameter of $6.63 \mathrm{~cm}$. The control recorded the lowest diameter of $5.67 \mathrm{~cm}$. 


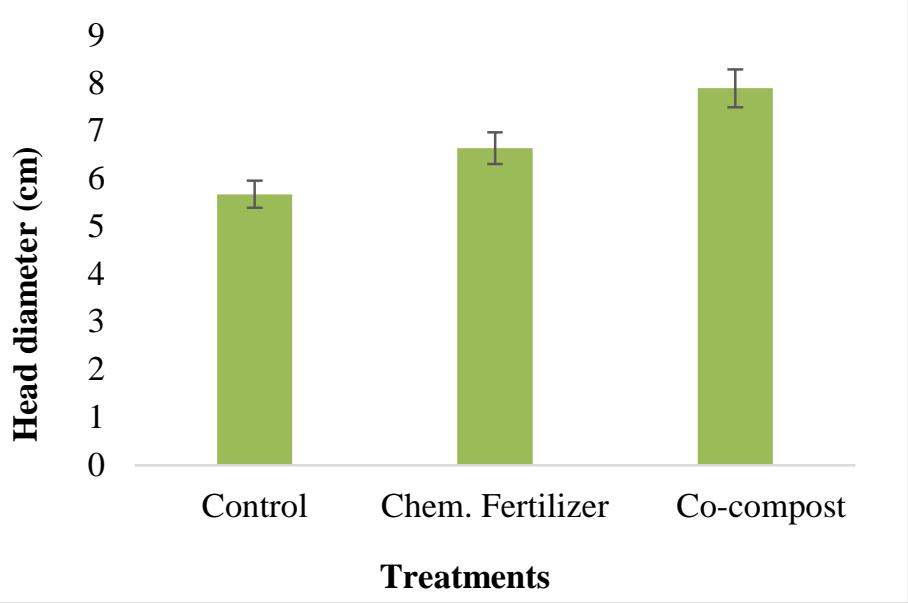

Figure 1 Head diameter of cabbage after harvest on the various treatments.

\section{Head Weight of Cabbage}

Cabbage heads harvested from plots treated with the co-compost recorded the highest weight $(53.35 \mathrm{~g})$. This was significantly higher $(\mathrm{p}<0.05)$ than that recorded for heads harvested from plots treated with the chemical fertilizer $(32.9 \mathrm{~g})$ and control $(31.4 \mathrm{~g})$. There was however no significant difference between cabbage heads harvested from chemical fertilizer plots and control plots (Figure 2).

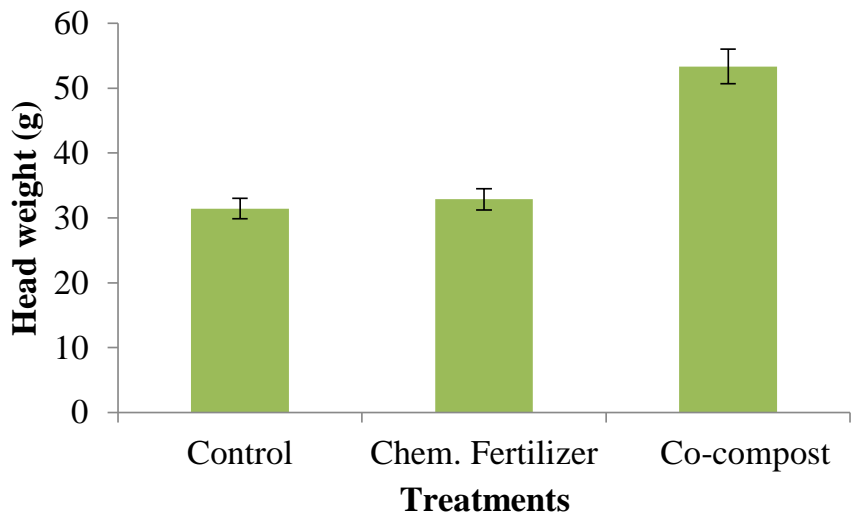

Figure 2 Head weight of cabbage after harvest on the various treatments.

\section{Number of Leaves of Lettuce}

The number of leaves increased steadily with lettuce cultivated with co-compost having the least number of leaves. This continued till the third week after which there was a rapid increase in the number of leaves of lettuce cultivated with cocompost followed by plants cultivated on plots treated with chemical fertilizer and control being the least (Figure 3).

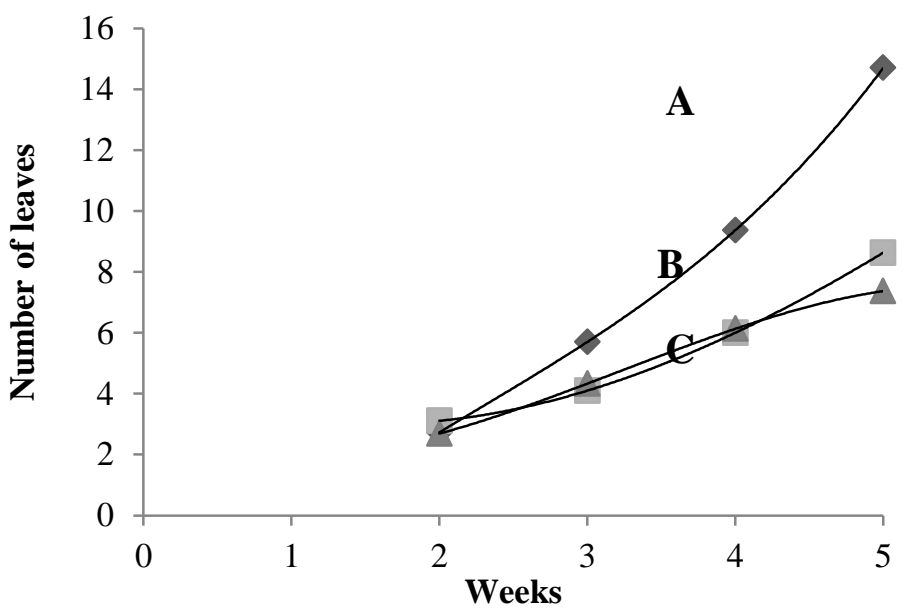

Figure 3 Number of leaves developed within 5 weeks of cultivation of lettuce on (A) co-compost, (B) chemical fertilizer and (C) control plots.

\section{Plant Height of Lettuce}

During the first two weeks after transplanting (2WAP), plant heights were almost within the same range among all the treatments. However, there was a sharp decline in plant heights among all the treatments from 2 WAP until the third week after which a rapid increase occurred till the fifth week. Lettuce cultivated on plots treated with co-compost had the highest plant heights followed by chemical fertilizer and control having the least (Figure 4). These differences were statistically significant $(\mathrm{p}<0.05)$.

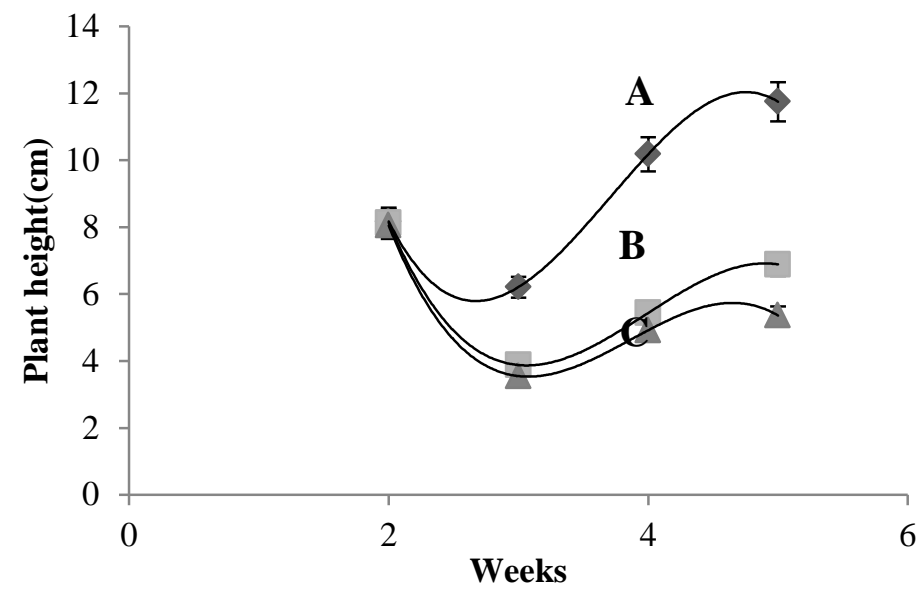

Figure 4 Plant heights recorded within 5 weeks of cultivation of lettuce on (A) co-compost, (B) chemical fertilizer and (C) control plots.

\section{Plant Weight after Harvesting}

The weights of plants obtained after harvesting showed a wide variation between the lettuce cultivated on plots treated with co-compost and lettuce cultivated with chemical fertilizer as well as those without any treatment (Figure 5). This difference was highly significant $(\mathrm{p}<0.05)$ with that of co-compost recording the highest value of $190.6 \mathrm{~g}$ against $52.8 \mathrm{~g}$ and $29.5 \mathrm{~g}$ for chemical fertilizer and control respectively.

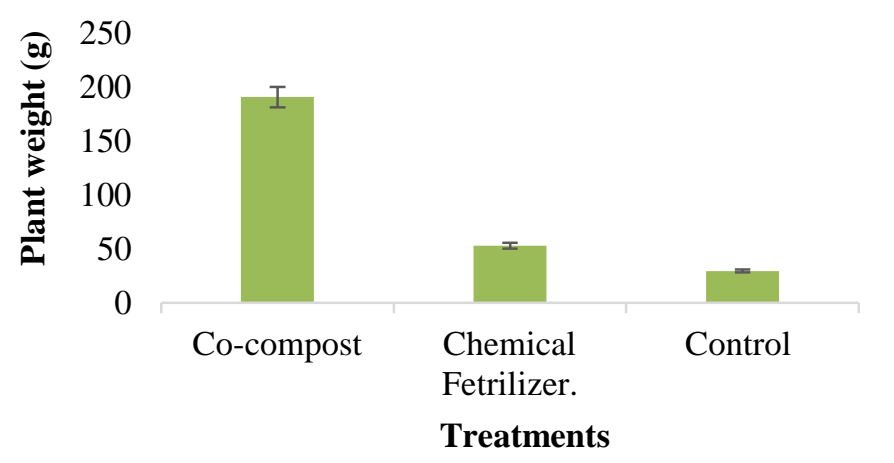

Figure 5 Plant weights after harvesting of lettuce on the various treatments.

\section{Root Weight after Harvesting (Lettuce)}

The measurements taken from the roots of the lettuce plants after harvesting showed significant different $(\mathrm{p}<0.05)$ between co-compost and the other treatments. Plants cultivated on soil treated with co-compost to have the highest weight $(18.8 \mathrm{~g})$. This was followed by those cultivated with chemical fertilizer $(4.47 \mathrm{~g})$ and plants from the control plots having the least root weight $(3.34 \mathrm{~g})$ (Figure 6). 
25

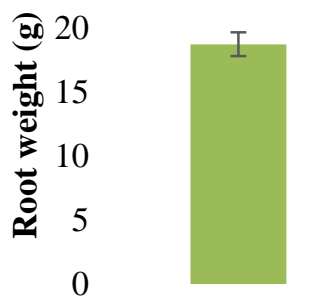

Co-compost

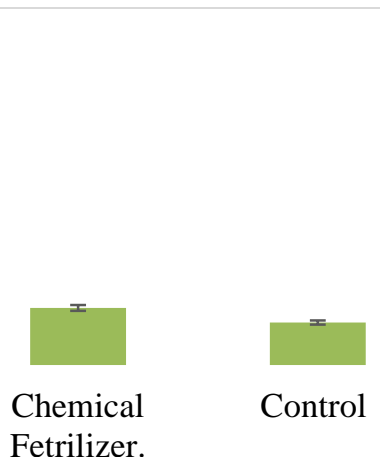

Fetrilizer.

\section{Treatments}

Figure 6 Root weight of lettuce after harvest on the various treatments.

Lettuce plants from plots treated with co-compost had the highest root weight. This was significantly different $(\mathrm{p}<0.05)$ from those harvested from plots treated with chemical fertilizer and the control plots.

\section{Microbial Load on Cabbage Heads after Harvest}

There was highly significant difference $(\mathrm{p}<0.05)$ in the microbial load on cabbage heads between treatments $(\mathrm{CFU} / \mathrm{ml})$ counted after $24 \mathrm{hrs}$ of incubation. The control recorded the highest microbial load of $2.45 \times 10^{9}(\mathrm{CFU} / \mathrm{ml})$ followed by chemical fertilizer of $5.2 \times 10^{8}(\mathrm{CFU} / \mathrm{ml})$ and the co-compost recording the lowest microbial load of $1.18 \times 10^{7}(\mathrm{CFU} / \mathrm{ml})$. There was also high significant difference between the chemical fertilizer treated plant and the co-compost (Figure 7).

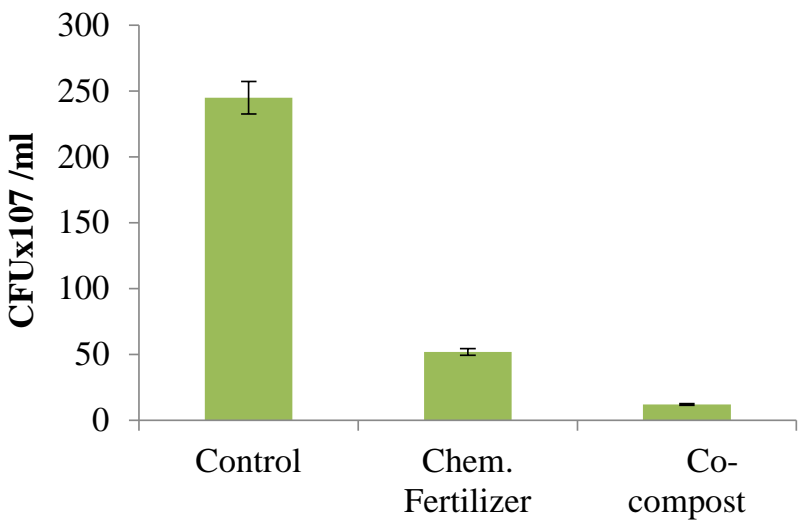

Treatments

Figure 7 Microbial load (CFU/ml) on cabbage after harvest on the various treatments.

The results (Table 2) confirmed the presence of faecal coliforms Salmonella spp., Shigella spp., Escherichia coli, and Klebsiella spp. in the three treatments plants. The various species were identified based on their ability to ferment manitol, sucrose, glucose, lactose, the ability to grow in citrate acid agar and react to catalase.

Table 2 Carbohydrate fermentation test of isolates from the various treatment plants

\begin{tabular}{|c|c|c|c|c|c|c|}
\hline \multirow[b]{2}{*}{ Isolated species } & \multicolumn{4}{|c|}{ Specific Carbohydrates } & \multirow[b]{2}{*}{ Citrate test } & \multirow[b]{2}{*}{ Catalase test } \\
\hline & Glucose & Manitol & Lactose & Sucrose & & \\
\hline Escherichia coli & $+/+$ & $+/+$ & + & $+/+$ & - & + \\
\hline Klebsiella spp. & $+/+$ & + & + & + & + & + \\
\hline Shigella spp. & + & + & - & - & - & + \\
\hline Salmonella spp. & + & $N D$ & - & + & + & + \\
\hline
\end{tabular}

\section{DISCUSSIONS}

\section{Head Diameter and Head Weight of Cabbage}

Results from this study shows that the dried faecal sludge and municipal waste co-compost has the potential to help farmers increase their yield in cabbage production. This is because the co-compost performed far better than the chemical fertilizer and the control in terms of yield. Cabbage is a heavy feeder thus utilizes more nutrients in the soil than other crops like legumes and cereals (Pierce, 1987; Chaurasia et al., 2012).

Co-compost as organic fertilizer has high nutrient content, with higher concentration of macronutrients such as nitrogen, phosphorus and potassium (Asghar et al., 2006; Farrell and Jones, 2010; Cofie et al., 2016). It does not only supply macronutrients but they are also valuable sources of micronutrients such as iron, cobalt, chromium, copper, manganese, zinc and molybdenum which helps to coordinate a range of physiological functions. It also promotes growth of earthworms and other beneficial soil organisms including nitrifying bacteria (Bierman and Rosen, 2005; Kästner and Miltner, 2016; Ren et al., 2017). Yield of cabbage in particular is affected by the supply of nitrogen during cultivation (More, 2006). Thus the high level of nitrogen $(\mathrm{N})$ in the co-compost couple with the other benefits above could have accounted for the higher yield compared with the other treatments.

This experiment was carried out in the dry season, where the soil was very dry, placing a lot of stress on the plants. Water was provided through manual irrigation (using watering cans). It is of interest to note here that the low humidity coupled with transpiration means that the soil lost a lot of water even after watering (Taiz and Zieger, 2002; Stewart and Peterson, 2015). However, the ability of co-compost treated soil to retain a relatively appreciable amount of water due to increase in soil aggregation and decrease in bulk density as a result of the presence of organic carbon in the co-compost treated soils makes water available for crops use over relatively longer periods after watering. Co-compost serves as a soil amendment and has the capacity to retain moisture which helps with the uptake of nutrients from the soil by plant (Evanylo et al., 2008; Vengadaramana and Jashothan, 2012). This capacity of co-compost gave it competitive advantage over the other treatments.

\section{Number of Leaves, Plant Height, Weight and Root Weight of Lettuce}

Data from the yield parameters show that the co-compost could be good if not better replacement for chemical fertilizers as indicated by (Smith et al., 2001; Diacono and Montemurro, 2011). The Co-Composting Council in the year 2000 has observed that co-compost improves soil structure, porosity and density thus creating a better plant root environment. This could have accounted for the high root mass recorded for the plants cultivated with the co-compost. Cocompost also improves water holding capacity thus reducing water loss and leaching in sandy soils. This can lead to high plant and root weight as there will be enough water for the plants to utilize. Furthermore, co-compost has the ability to replenish plant nutrients depleted by harvested produce (Zenz et al., 1976; Diener et al., 1993; Cofie et al., 2016; Moya et al., 2017). Lettuce plants harvested from control plots recorded the least values for all parameters. This may be due to the low nutrient composition of the soil at the experimental site.

\section{The Microbial load on cabbage heads after harvest.}

Preliminary microbial load analysis was conducted on the dried faecal sludge and municipal waste co-compost before application. The results obtained after analyzing the microbial loads on cabbage heads from the various treatments demonstrate that the dried faecal sludge and municipal waste co-compost has a great potential for farmers and consumers in vegetable production. This is because the co-compost recorded the lowest microbial load count than the chemical fertilizer and the control.

The low microbial load on the co-compost compared to other treatments is not very surprising. This is because activities of microorganisms are affected by substrate availability, temperature, $\mathrm{pH}$, soil moisture, enzyme activity and predation (Balser et al., 2000; Chaer et al., 2009). The decrease in the microbial load from the treatment with co-compost and chemical fertilization could be as a result of the addition of nitrogen $(\mathrm{N})$ to the soil which has resulted in decreased soil $\mathrm{pH}$ (Maraun et al., 2001), the related soil chemical changes that arise as $\mathrm{pH}$ changes, may be a major factor controlling soil microbial actions and biomass (Mamilov et al., 2000; Blagodatskaya and Kuzyakov, 2008). The decreases in soil $\mathrm{pH}$ as a result of nitrogen addition causes acidification due to ammonia oxidation by the nitrifying bacteria and $\mathrm{NO}_{3}{ }^{-}$leaching which could affect the 
growth and activities of the microorganism (Rasmussen and Rohde, 1989; Cytryn et al., 2012)

A number of authors have reported the presences of heavy metals such as copper, lead and mercury in dried faecal sludge and municipal waste co-compost (Hyde, 1976). These heavy metals are noted to inhibit the growth of soil microorganism especially their multiplication (Nishino et al., 2007). This (though not analysis) might have resulted in the reduction in microbial load on co-compost treatment plants as compared to the chemical fertilizer treatment and the control plants as they are injurious to microorganisms even at the low concentration by forming complexes with protein molecules which render them inactive due to inactivation of enzymes (Mills and Colwell, 1977)

The presence of microbes on the co-compost especially the possible pathogenic spp could also be as a result of the co-composting time. Time is an importan factor to the survival of pathogens in co-composted matter. The longer the cocomposting duration, the lower the survival rate of pathogens. Previous study by (Salkioja-Salonen, 1983; Redlinger et al., 2001) shown that toilet waste has to be co-composted for at least six months even during summer to reduce to appreciable levels the pathogenic microbial content.

The temperature of exposure of co-compost is another factor for the survival of most bacterial pathogens. Report by (Cooper and Golueke, 1982; Berge et al., 2009) indicated that temperatures in well-managed co-compost operation are normally in a range of 50 to $65^{\circ} \mathrm{C}$. Such temperatures are well above the thermal death points of mesophilic pathogens. As the temperature of the co-composting process increases pathogens are usually destroyed as they reach their therma death points. There is a relationship between temperature and time, high temperature for a short period or a lower temperature for a longer period may be equally effective. Study by (Epstein, 2001) revealed that high temperatures were extremely effective in the destruction of pathogens.

The method of co-composting may also have an effect on type and survival of microorganisms in co-composts. This was supported by (Pereira-Neto et al. 1986) that static aerated piles were more efficient than windrows in the inactivation of the indicator organisms. It was reported that, in static aerated piles E. coli was reduced below the detection level, faecal streptococci were reduced to less than $10^{2}$ cfu per gram and Salmonella were completely eliminated after 32 days of co-composting (Gaby, 1975; Hay, 1996). In contrast, all of these organisms were still detectable at the end of the windrow co-composting process for the co-compost used for this experiment.

The level of microbial mean population on plots treated with co-compost could also be associated with leaves morphology, the broad leave which easily come into contact with the ground, accumulation of dirt by the rough surface and subsequent bacteria adhesion (Seow et al., 2012; Cardamone et al., 2015). It could also be due to the ability of some microorganisms to survive in plants. For instance $E$. coli has the capability of attachment to the interior of vegetable pores and has a tendency to form aggregate association (Seo and Frank, 1999; Wachtel et al., 2002). The method of watering with "can" could also be a factor for transmission of microorganisms to leave surfaces through splashing.

Furthermore, the results from this study confirmed the presence of faecal coliforms Salmonella spp., Shigella spp., Escherichia coli, and Klebsiella spp. in the three treatments. The cross contamination of feacal coliforms could be attributed to several factors such as the source of water used in the production (Hamilton et al., 2006; Ben Said et al., 2016), the grazing by livestock's in the area during the off season with their excreta and the closeness of the experimental field to the co-compost pit.

\section{CONCLUSSION}

The results obtained from this study shows that the dried faecal sludge and municipal waste co-compost has better performance in terms of yield and microbial load when used for cabbage and lettuce production. Moreover, it requires appropriate composting technique to reduce the microbial load to the minimum level. The higher yield coupled with the relatively lower microbial load on vegetable cultivated on plots treated with the co-compost makes it a good source of plant nutrients to be recommended to farmers. Furthermore, due to the increase in waste production with economic growth and industrialization, emphasis should be laid, especially in municipal cities of developing countries, on adopting appropriate waste management systems that, promote recycling of waste, and encourage utilization of faecal sludge to produce fertilizers for supporting agricultural needs. This will go a long way to solve the possibly adverse effect cause by unscientific disposal of waste on all components of the environment including human health.

Acknowledgement: The authors are grateful to the entire staff of Biotechnology department and the technicians of Spanish laboratory in University for Development Studies, Tamale for the facilities provided during the study.

\section{REFERENCES}

Agbede, O., Ajagbe, W., 2004. Solid Waste Management in South Western Nigeria. International Journal of Environmental 2, 92-97.
Asghar, H., Ishaq, M., Zahir, Z., Khalid, M., Arshad, M., 2006. Response of radish to integrated use of nitrogen fertilizer and recycled organic waste. Pakistan Journal of Botany 38, 691

Balser, T.C., Kinzig, A.P., Firestone, M.K., 2000. Linking soil microbial communities and ecosystem functioning, $\mathrm{PhD}$ dissertation. University of California-Berkeley, Berkeley, CA.

Banar, M., Cokaygil, Z., Ozkan, A., 2009. Life cycle assessment of solid waste management options for Eskisehir, Turkey. Waste management 29, 54-62. doi.org/10.1016/j.wasman.2007.12.006

Ben Said, L., Klibi, N., Dziri, R., Borgo, F., Boudabous, A., Ben Slama, K. Torres, C., 2016. Prevalence, antimicrobial resistance and genetic lineages of Enterococcus spp. from vegetable food, soil and irrigation water in farm environments in Tunisia. Journal of the science of food and agriculture 96, 1627 1633. DOI: $10.1002 /$ jsfa. 7264

Berge, A.C.B., Glanville, T.D., Millner, P.D., Klingborg, D.J., 2009. Methods and microbial risks associated with composting of animal carcasses in the United States. Journal of the American Veterinary Medical Association 234, 47-56. https://doi.org/10.2460/javma.234.1.47

Bierman, P.M., Rosen, C.J., 2005. Nutrient cycling and maintaining soil fertility in fruit and vegetable crop systems. University of Minesota.

Blagodatskaya, E., Kuzyakov, Y., 2008. Mechanisms of real and apparent priming effects and their dependence on soil microbial biomass and community structure: critical review. Biology and Fertility of Soils 45, 115-131 https://doi.org/10.1007/s00374-008-0334-y

Cardamone, C., Aleo, A., Mammina, C., Oliveri, G., Di Noto, A.M., 2015 Assessment of the microbiological quality of fresh produce on sale in Sicily, Italy: preliminary results. Journal of Biological Research-Thessaloniki 22, 3 . https://doi.org/10.1186/s40709-015-0026-3

Chaer, G., Fernandes, M., Myrold, D., Bottomley, P., 2009. Comparative resistance and resilience of soil microbial communities and enzyme activities in adjacent native forest and agricultural soils. Microbial ecology 58, 414-424. https://doi.org/10.1007/s00248-009-9508-x

Chaurasia, S., Prasad, R., Yadava, R., Singh, D., 2012. Nutrient Management in Vegetable Crops for Sustainable Production. Green Agriculture: Newer Technologies, 281.

Cofie, O., Nikiema, J., Impraim, R., Adamtey, N., Paul, J., Koné, D., 2016. Cocomposting of solid waste and fecal sludge for nutrient and organic matter recovery. IWMI.

Cooper, R., Golueke, C., 1982. Survival of enteric bacteria and viruses in compost and its leachate.

Cordell, D., Drangert, J.-O., White, S., 2009. The story of phosphorus: Global food security and food for thought. Global Environmental Change 19, 292-305. doi:https://doi.org/10.1016/j.gloenvcha.2008.10.009

Cordell, D., Rosemarin, A., Schröder, J.J., Smit, A.L., 2011. Towards global phosphorus security: A systems framework for phosphorus recovery and reuse

$\begin{array}{lcr}\text { options. } & \text { Chemosphere } & 84 \\ \text { doi:https://doi.org/10.1016/j.chemosphere.2011.02.032 }\end{array}$

Cytryn, E., Levkovitch, I., Negreanu, Y., Dowd, S., Frenk, S., Silber, A., 2012 Impact of short-term acidification on nitrification and nitrifying bacterial community dynamics in soilless cultivation media. Applied and environmental microbiology 78 , 6576-6582.

\section{http://aem.asm.org/doi:10.1128/AEM.01545-12}

Diacono, M., Montemurro, F., 2011. Long-term effects of organic amendments on soil fertility, Sustainable Agriculture Volume 2, Springer, pp. 761-786. https://doi.org/10.1007/978-94-007-0394-0 34

Diener, R.G., Collins, A.R., Martin, J.H., Bryan, W., 1993. Composting of source-separated municipal solid waste for agricultural utilization-A conceptual approach for closing the loop. Applied Engineering in Agriculture 9, 427-436.

doi: $10.13031 / 2013.26005$

Epstein, E., 2001. Human pathogens: hazards, controls, and precautions in compost. Compost utilization in horticultural cropping systems 17, 361-380.

Escobar, M.O., Hue, N., Pandalai, S., 2007. Current developments in organic farming. Recent Research Development in Soil Science 2, 29-62.

Esrey, S.A., Gough, J., Rapaport, D., Sawyer, R., Simpson-Hébert, M., Vargas, J., Winblad, U., 1998. Ecological sanitation. Sida.

Evanylo, G., Sherony, C., Spargo, J., Starner, D., Brosius, M., Haering, K., 2008. Soil and water environmental effects of fertilizer-, manure-, and compost-based fertility practices in an organic vegetable cropping system. Agriculture,
Ecosystems
\& Environment
127 ,
$50-58$

https://doi.org/10.1016/j.agee.2008.02.014

Farrell, M., Jones, D., 2010. Food waste composting: Its use as a pea $\begin{array}{llll}\text { replacement. Waste } & \text { Management } & \text { 1495-1501. }\end{array}$ https://doi.org/10.1016/j.wasman.2010.01.032

Feachem, R., Bradley, D., Garelick, H., Mara, D., 1983. Sanitation and Disease: Health aspects of excreta and wastewater management, World Bank Study. Water Supply Sanitation 3

Fullen, M.A., Booth, C.A., Hammond, F.N., Tannahill, K., Awopetu, S.O., Awopetu, R.G., Coker, A.O., Awopetu, M.S., 2013. Reduction, Reuse and Recycling of Solid Waste in The Makurdi Metropolitan Area of Nigeria: Public Opinions and Perceptions. International Journal of Education and Research. 
Gaby, W.L., 1975. Evaluation of health hazards associated with solid waste/sewage sludge mixtures.

Garrity, G., 2006. Bergey's Manual ${ }^{\circledR}$ of Systematic Bacteriology: Volume Two: The Proteobacteria, Part A Introductory Essays. Springer Science \& Business Media.

Gu, B., Jiang, S., Wang, H., Wang, Z., Jia, R., Yang, J., He, S., Cheng, R., 2016 Characterization, quantification and management of China's municipal solid waste in spatiotemporal distributions: A review. Waste Management https://doi.org/10.1016/j.wasman.2016.11.039

Guzha, E., Nhapi, I., Rockstrom, J., 2005. An assessment of the effect of human faeces and urine on maize production and water productivity. Physics and Chemistry of the Earth, Parts A/B/C 30, 840-845 https://doi.org/10.1016/j.pce.2005.08.028

Hamilton, A.J., Stagnitti, F., Premier, R., Boland, A.-M., Hale, G., 2006 Quantitative microbial risk assessment models for consumption of raw vegetables irrigated with reclaimed water. Applied and environmental microbiology 72 3284-3290. https//doi: 10.1128/AEM.72.5.3284-3290.2006

Hay, J.C., 1996. Pathogen destruction and biosolids composting. Biocycle 37, $67-$ 76.

Hering, J.G., 2012. An end to waste? Science 337, 623-623.

Hotta, Y., 2014. 3R Policy Indicator Factsheets-Discussion Paper. Asia Resource Circulation Policy Research Group. Kanagawa, Japan: Institute for Global

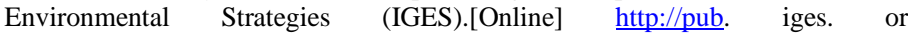
jp/modules/envirolib/upload/4977/attach/3RIndicator_B5report_web. (Accessed 23 April, 2014).

Hyde, H.C., 1976. Utilization of wastewater sludge for agricultural soil enrichment. Journal (Water Pollution Control Federation), 77-90.

Kästner, M., Miltner, A., 2016. Application of compost for effective bioremediation of organic contaminants and pollutants in soil. Applied $\begin{array}{llll}\text { microbiology and } \quad \text { biotechnology } & 100,\end{array}$ https://doi.org/10.1007/s00253-016-7378-y

KUMAR, G.S., 2013. Effect of Organic Manures on Growth, Root Yield and Quality of Carrot (Daucus Carota L.), Dr. Ysr Horticultural University.

Magrinho, A., Didelet, F., Semiao, V., 2006. Municipal solid waste disposal in $\begin{array}{llll}\text { Portugal. Waste } & \text { Management } & \text { 26, }\end{array}$ doi:https://doi.org/10.1016/j.wasman.2006.03.009

Mamilov, A.S., Byzov, B., Pokarzhevskii, A., Zvyagintsev, D., 2000. Regulation of the biomass and activity of soil microorganisms by microfauna. Microbiology 69, 612-621. https://doi.org/10.1007/BF02756818

Maraun, M., Alphei, J., Beste, P., Bonkowski, M., Buryn, R., Migge, S., Peter, M., Schaefer, M., Scheu, S., 2001. Indirect effects of carbon and nutrient amendments on the soil meso-and microfauna of a beechwood. Biology and Fertility of Soils 34, 222-229. https://doi.org/10.1007/s003740100403

Matsuda, T., Hirai, Y., Asari, M., Yano, J., Miura, T., Ii, R., Sakai, S.-i., 2017 Monitoring environmental burden reduction from household waste prevention. Waste Management. https://doi.org/10.1016/j.wasman.2017.10.014

Miezah, K., Obiri-Danso, K., Kádár, Z., Fei-Baffoe, B., Mensah, M.Y., 2015 Municipal solid waste characterization and quantification as a measure towards effective waste management in Ghana. Waste Management 46, 15-27. http://dx.doi.org/10.1016/j.wasman.2015.09.009

Mills, A.L., Colwell, R.R., 1977. Microbiological effects of metal ions in Chesapeake Bay water and sediment. Bulletin of environmental contamination and toxicology 18, 99-103. https://doi.org/10.1007/BF01686313

More, K., 2006. Response of cabbage (Brassica Oleracea Var Capitata) transplants to nitrogen, phosphorus and potassium nutrition.

Moya, B., Parker, A., Sakrabani, R., Mesa, B., 2017. Evaluating the Efficacy of Fertilisers Derived from Human Excreta in Agriculture and Their Perception in Antananarivo, Madagascar. Waste and Biomass Valorization, 112.https://doi.org/10.1007/s12649-017-0113-9

Nabegu, A.B., 2010. An analysis of municipal solid waste in Kano metropolis, Nigeria. Journal of Human Ecology 31, 111-119.

Nagabooshnam, J.K., 2011. Solid waste generation and composition in Gaborone, Botswana, Potential for resource recovery. Linköping University.

Nartey, E.G., 2013. Faecal Sludge Reuse in Urban and Peri-Urban Crop Production, University of Ghana.

Nishino, K., Nikaido, E., Yamaguchi, A., 2007. Regulation of multidrug efflux systems involved in multidrug and metal resistance of Salmonella enterica serovar Typhimurium. Journal of bacteriology 189, 9066-9075. https/ doi 10.1128/JB.01045-07

Niwagaba, C., Nalubega, M., Vinnerås, B., Sundberg, C., Jönsson, H., 2009. Bench-scale composting of source-separated human faeces for sanitation. Waste management 29, 585-589. https://doi.org/10.1016/j.wasman.2008.06.022

Oelhaf, R.C., 1978. Organic agriculture. Economic and ecological comparisons with conventional methods. John Wiley and Sons. https://doi.org/10.1007/BF01965614

Okot-Okumu, J., 2012. Solid waste management in African cities-East Africa, Waste Management-An Integrated Vision, InTech. DOI: 10.5772/50241

Pereira-Neto, J., Stentiford, E., Mara, D., 1986. Comparison of windrows and aerated static piles for refuse/sludge composting, International Symposium on
Compost Production Quality and

Use.

Pierce, L.C., 1987. Vegetables: characteristics, production and marketing, John Wiley.

Rasmussen, P.E., Rohde, C., 1989. Soil acidification from ammonium-nitrogen fertilization in moldboard plow and stubble-mulch wheat-fallow tillage. Soil Science Society of America Journal 53, 119-122. doi:10.2136/sssaj1989.03615995005300010022x

Redlinger, T., Graham, J., Corella-Barud, V., Avitia, R., 2001. Survival of fecal coliforms in dry-composting toilets. Applied and environmental microbiology 67, 4036-4040. doi: 10.1128/AEM.67.9.4036-4040.2001

Reiner, K., 2010. Catalase test protocol.

Reiner, K., 2012. Carbohydrate Fermentation Protocol

Rekhi, R., Benbi, D., Singh, B., 2000. Effect of fertilizers and organic manures on crop yields and soil properties in rice-wheat cropping system. Long-term soil fertility experiments in rice-wheat cropping systems. Rice-Wheat Consortium Paper Series 6, 1-6.

Ren, X., Zeng, G., Tang, L., Wang, J., Wan, J., Wang, J., Deng, Y., Liu, Y., Peng, B., 2017. The potential impact on the biodegradation of organic pollutants from composting technology for soil remediation. Waste Management. https://portal.lib.ku.ac.th:11864/10.1016/j.wasman.2017.11.032

Richert, A., Gensch, R., Jönsson, H., Stenström, T.A., Dagerskog, L., 2010. Practical guidance on the use of urine in crop production, SEI.

Salkioja-Salonen, M., 1983. Käymäläkomposti ja kompostikäymälä. Teoksessa Kompostikäymäläopas. Pehmeän teknologian seuran julkaisuja 10, 49-73.

Schönning, C., Leeming, R., Stenström, T.A., 2002. Faecal contamination of source-separated human urine based on the content of faecal sterols. Water Research 36, 1965-1972. https://doi.org/10.1016/S0043-1354(01)00427-4

Schuster-Wallace, C., Wild, C., Metcalfe, C., 2015. Valuing human waste as an energy resource: A research brief assessing the global wealth in waste, Hamilton: United Nations University Institute for Water. Environment and Health (UNUINWEH).[Retrieved from].

Seo, K., Frank, J., 1999. Attachment of Escherichia coli O157: H7 to lettuce leaf surface and bacterial viability in response to chlorine treatment as demonstrated by using confocal scanning laser microscopy. Journal of food protection 62, 3-9. doi/abs/10.4315/0362-028X-62.1.3

Seow, J., Ágoston, R., Phua, L., Yuk, H.-G., 2012. Microbiological quality of fresh vegetables and fruits sold in Singapore. Food Control 25, 39-44. https://doi.org/10.1016/j.foodcont.2011.10.017

Shiralipour, A., McConnell, D.B., Smith, W.H., 1992. Physical and chemical properties of soils as affected by municipal solid waste compost application Biomass and Bioenergy 3, 261-266. https://doi.org/10.1016/09619534(92)90030-T

Simmons, J.S., 1926. A culture medium for differentiating organisms of typhoidcolon aerogenes groups and for isolation of certain fungi. The Journal of Infectious Diseases, 209-214.

Smith, D.C., Beharee, V., Hughes, J.C., 2001. The effects of composts produced by a simple composting procedure on the yields of Swiss chard (Beta vulgaris L. var. flavescens) and common bean (Phaseolus vulgaris L. var. nanus). Scientia horticulturae 91, 393-406. https://doi.org/10.1016/S0304-4238(01)00273-4

Soliva Torrentó, M., Felipó, M., 2002. Organic wastes as a resource for Mediterranean soils, Workshop "Biological treatment of biodegradable wastesTechnical aspects".

Stewart, B., Peterson, G., 2015. Managing green water in dryland agriculture Agronomy Journal 107, 1544-1553. doi:10.2134/agronj14.0038

Taiz, L., Zieger, E., 2002. Plant Physiology 3rd edition. Sinauer Associate. Inc., Publishers Sunderland, Massachusetts.

UNEP-IETC, H., 1996. International source book on environmentally sound technologies for municipal solid waste management, United Nations Environment Programme (UNEP). International Environmental Technology Centre (IETC).

Valkenburg, C., Gerber, M., Walton, C., Jones, S., Thompson, B., Stevens, D.J. 2008. Municipal solid waste (MSW) to liquid fuels synthesis, volume 1 Availability of feedstock and technology. Richland, WA (US): Pacific Northwest National Laboratory, December. gov/main/publications/external/technicalBreports/PNNLY18144. pdf. Accessed October 30, 2009

Vengadaramana, A., Jashothan, P., 2012. Effect of organic fertilizers on the water holding capacity of soil in different terrains of Jaffna peninsula in Sri Lanka. J. Nat. Prod. Plant Resour 2, 500-503.

Wachtel, M.R., Whitehand, L.C., Mandrell, R.E., 2002. Association of Escherichia coli O157: H7 with preharvest leaf lettuce upon exposure to contaminated irrigation water. Journal of food protection 65, 18-25 https://doi.org/10.4315/0362-028X-65.1.18

Wilson, D.C., Rodic, L., Cowing, M.J., Velis, C.A., Whiteman, A.D., Scheinberg, A., Vilches, R., Masterson, D., Stretz, J., Oelz, B., 2015 'Wasteaware' benchmark indicators for integrated sustainable waste management in cities. Waste Management 35, 329-342. https://doi.org/10.1016/j.wasman.2014.10.006 
Wilson, D.C., Rodic, L., Cowing, M.J., Whiteman, A., Stretz, J., Scheinberg, A., 2013. Benchmark Indicators for Integrated \& Sustainable Waste Management (ISWM), ISWA World Congress.

Wolgast, M., 1993. Recycling system. Brochure produced by WM-Ekologen, $\mathrm{AB}$, Stockholm, Sweden.

Yadav, K.D., Tare, V., Ahammed, M.M., 2010. Vermicomposting of sourceseparated human faeces for nutrient recycling. Waste Management 30, 50-56. https://doi.org/10.1016/j.wasman.2009.09.034

Yano, J., Sakai, S.-i., 2016. Waste prevention indicators and their implications from a life cycle perspective: a review. Journal of Material Cycles and Waste Management 18, 38-56. https://doi.org/10.1007/s10163-015-0406-7

Zenz, D.R., Peterson, J.R., Brooman, D.L., Lue-Hing, C., 1976. Environmental impacts of land application of sludge. Journal (Water Pollution Control Federation), 2332-2342 